errors-namely better than, for instance, our own Danish political system would be able to do it. It is very important that we manage to tolerate the errors which will inevitably be committed by the Greenland Representative Council.

We should also cherish the hope that the Greenlanders, who now number about 50,000 , will be able-during the inevitable technological development - to preserve due respect for the Eskimo heritage and live a wellconsidered balance between newly acquired technical capabilities and traditional hunter skills (Fig. 9).

\section{REFERENCES}

BACH, H.C.\& TAAGHOLT, Jørgen (1976). Udviklingstendenser for Grønland. - in Danish. (Development trends for Greenland: Resources and environment in global perspective.) Commission for Scientific Research in Greenland, Nyt Nordisk Forlag, Copenhagen, Denmark: $248 \mathrm{pp}$., illustr.

BACH, H. C. \& TAAGHOLT, Jørgen (1977). Greenland and the Arctic Region - in the Light of Defence Policies. Information and Welfare Service of the Danish Defence, Copenhagen, Denmark; 55 pp., illustr.

FOIGHEL, Isi (1980). The Home Rule in Greenland. Meddelelser om Gronland, Man \& Soc., 1, 1980 [not available for checking].

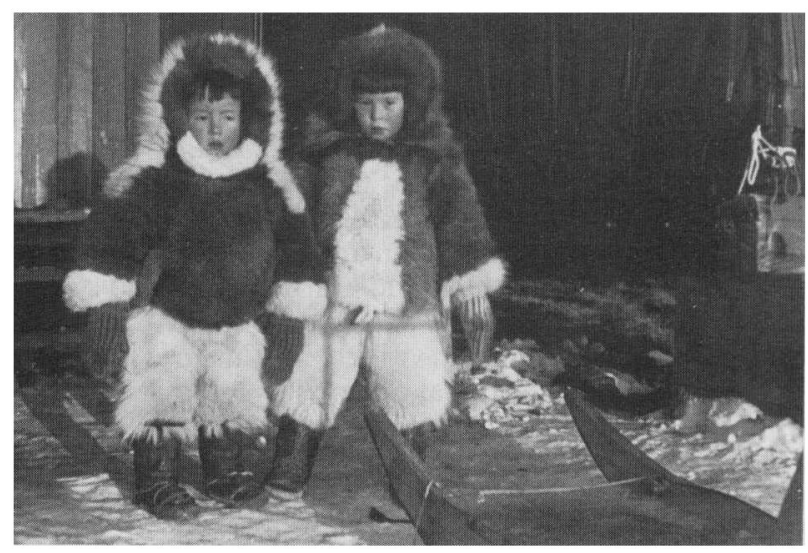

Fig. 9. The youth of today is the hope for the future, with due respect for the Eskimo cultural heritage and a life that is balanced between recently acquired technical skills and traditional hunter skills.

LYNGE, Finn (1977). Tanker $i$ et Bulldozerspor. - in Danish/ Greenlandic. Det Gronlandske Forlag, Godthåb, Greenland: $155 \mathrm{pp}$.

TAAGHOLT, Jørgen (1978). Arctic resources. Arctic Bulletin, 2(14), pp. 347-52, illustr.

\title{
Multi-million-dollars Forgeries in Fur-trade Documents Uncovered
}

A large West German fur and leather trader has been using forged documents to carry on a multi-million-dollars traffic in Ocelot (Felis pardelis) and rare crocodile hides from Paraguay, an international conservation agency revealed in Geneva very recently. For the past three years the Frankfurt-based trader has been using the documents to import skins of thousands of endangered animals worth some US\$12 millions. On hearing news of the scandal, Paraguay's President, General Alfredo Stroessner, promised to take immediate action to stop the trade and save his country's vanishing wildlife resources.

The forgeries were uncovered by the Secretariat of the Convention on International Trade in Endangered Species (CITES,* the 1973 Washington Convention), which is administered on behalf of the United Nations Environment Programme by the International Union for Conservation of Nature and Natural Resources. Both Paraguay and West Germany are among the 62 members of the Convention.

CITES Secretary-General, Peter Sand, remarked: 'In the past, when we have uncovered instances of the illegal wildlife trade, it was only the tip of the iceberg; this time we have found the iceberg itself.' Thus CITES has found that, since 1977, the company has been using false permits issued in Paraguay and purporting to authorize the export of more than 200,000 caiman crocodile hides (Caiman sp.), 40,000 Ocelot skins, and a total of 140,000 fur-skins of other endangered animals such as otters (Lutra sp.). Currently, an Ocelot coat sells for up to $\$ 40,000$ in West Germany.

Several of the endangered species listed on the permits are not native to Paraguay, and must therefore have been smuggled into the country from neighbouring Brazil,

*The CITES secretariat shares the same headquarters with IUCN and WWF at the addreşs given below (on right).
Argentina, or Bolivia. Brazil has a total export ban on all trade in wildlife and wildlife products, so the smugglers have probably been using Paraguay as a convenient staging post for entry into the lucrative West German market. Department stores in Frankfurt and Munich openly advertise coats made from Brazilian Ocelot.

The uncovering of the forgeries represents a major triumph for CITES and its new international 'crosschecking' system which was introduced earlier this year. When nine export permits presented by the Frankfurt trader in West Germany were passed on by CITES to the Paraguayan authorities, they could find no evidence of the permits ever having been issued. The Paraguayan authorities discovered that the name of the exporter was not registered in their country; the forms had been printed in West Germany and the stamps and signatures were false. The company says that it recieved the documents with regular shipments from Paraguay, and that the West German customs had accepted them without difficulty during the preceding three years.

This is the eighth case of forged documents uncovered by the new CITES system already this year. Previous forgeries involved illegal ivory from Botswana, Chad, and Zaire; rare parrots and monkeys from Ghana; iguanas from Guatemala; fur-skins from Argentina, and live Bengal cats from Thailand. Peter Sand says 'Trade permits for endangered wildlife have become so valuable that they are being forged like banknotes. To foil the counterfeiters in future we plan--as with banknotesto print them on forgery-proof paper.'

Robert Lamb, Editor of IUCN Bulletin International Union for Conservation of Nature and Natural Resources Avenue du Mont-Blanc 1196 Gland, Switzerland. 